\title{
Activation of the vagal anti-inflammatory reflex by remote ischaemic conditioning in
} humans: experimental cross-over study.

Shaun M. May, ${ }^{* 1}$ Eric Chiang, ${ }^{1}$ Anna Reyes, ${ }^{2}$ Gladys Martir, ${ }^{2}$ Amour Patel, ${ }^{1}$ Shamir

Karmali, ${ }^{1}$ Sanjiv Patel, ${ }^{2}$ Simeon West, ${ }^{2}$ Ana Gutierrez del Arroyo, ${ }^{1}$ Alexander V. Gourine, ${ }^{3}$ Gareth L. Ackland ${ }^{1}$

Short title: Cardiac vagus and remote ischemic conditioning.

\section{*Joint lead authors}

1. William Harvey Research Institute, Barts and The London School of Medicine and

Dentistry, Queen Mary University of London,

2. University College Hospital NHS Trust, London UK

3. University College London.

\section{Corresponding author:}

Gareth Ackland PhD FRCA FFICM FHEA

ORCID: 0000-0003-0565-5164

Translational Medicine \& Therapeutics (218A),

William Harvey Research Institute, Barts and The London School of Medicine and Dentistry, Queen Mary University of London,

John Vane Science Centre, Charterhouse Square, London EC1M 6BQ. UK 
medRxiv preprint doi: https://doi.org/10.1101/2021.01.28.21249488; this version posted January 28, 2021. The copyright holder for this preprint (which was not certified by peer review) is the author/funder, who has granted medRxiv a license to display the preprint in It is made available under a CC-BY-NC-ND 4.0 International license .

Keywords: remote ischaemic conditioning; autonomic nervous systsem; vagus; inflammation; neutrophil; heart rate variability.

Funding: This work was supported by the British Heart Foundation (Ref: RG/14/4/30736 and RG/19/5/34463); British Journal of Anaesthesia/Royal College of Anaesthetists Basic Science Career Development Award; British Oxygen Company research chair grant, Royal College of Anaesthetists; UK National Institute for Health Research.

Ethics approval: London (Stanmore) Research Ethics Committee (16/LO/0634).

Study registration: researchregistry6482

\section{Authors' contributions:}

Shaun May: patient recruitment, Holter data capture and analysis; sample collection.

Eric Chiang: Holter data capture; flow cytometry- processing and analysis.

Anna Reyes, Gladys Martir, Amour Patel, Shamir Karmali,: patient recruitment and sample collection.

Simeon West, Sanjiv Patel: supervision/delivery of supraclavicular blocks.

Ana Gutierrez del Arroyo: flow cytometry- processing and analysis.

Alexander V. Gourine: study design, writing the manuscript.

Gareth L. Ackland: study design and oversight, Holter data capture and analysis; sample collection, writing the manuscript. 
medRxiv preprint doi: https://doi.org/10.1101/2021.01.28.21249488; this version posted January $28,2021$. The copyright holder for this preprint (which was not certified by peer review) is the author/funder, who has granted medRxiv a license to display the preprint in It is made available under a CC-BY-NC-ND 4.0 International license .

\begin{abstract}
BACKGROUND. Non-invasive approaches in humans that may activate the vagal antiinflammatory reflex are lacking. Neurons within the dorsal motor vagal nucleus (DMVN) activate both the vagal anti-inflammatory reflex (which regulates leukocyte trafficking by controlling neutrophil surface CD11b expression) and cardioprotection afforded by remote ischemic conditioning (RIC). We tested the hypothesis that RIC recruits vagal activity and activates the anti-inflammatory reflex in humans by reducing neutrophil $\left(\mathrm{CD} 16^{+}\right) \mathrm{CD} 11 \mathrm{~b}$ expression.
\end{abstract}

METHODS. Participants (age:50 \pm 19 years; 53\% female) underwent ultrasound-guided injection of local anaesthetic within the brachial plexus before applying $3 \times 8$ min cycles of brachial artery occlusion using a blood pressure cuff ( $\left.\mathrm{RIC}_{\text {block }}\right)$. RIC was repeated 6 weeks later without brachial plexus block. Masked analysers quantified vagal activity (heart rate variability) before, and 10 minutes after, the last RIC cycle. The primary outcome was RRinterval, compared between $\mathrm{RIC}_{\text {block }}$ and RIC. Secondary outcomes were time-domain, frequency-domain, and flow cytometric quantification of $\mathrm{CD} 16^{+} \mathrm{CD} 11 \mathrm{~b}$ expression in whole blood (incubated with lipopolysaccharide (LPS) or saline) compared between RIC block and RIC.

RESULTS. RIC increased RR-interval (lowered heart rate) by 40ms (95\% confidence intervals $(95 \% \mathrm{CI}): 13-66 ; \mathrm{n}=17 ; P=0.003)$. RR-interval did not change after $\mathrm{RIC}_{\mathrm{block}}$ (mean difference:20ms (95\%CI:-11 to 50); $P=0.19)$. High-frequency (vagal) modulation of heart rate was reduced after $\mathrm{RIC}_{\text {block}}$, but preserved after $\mathrm{RIC}(P<0.001)$. indicating RIC preserved vagal activity. LPS-induced CD16 ${ }^{+}$CD11 $b^{+}$expression was lower after RIC (3615 median fluorescence units (95\%CI:475-6754); $P=0.026$ ), compared with 2331 units (95\%CI:-3921 to 8582); $P=0.726)$ after $\mathrm{RIC}_{\text {block. }}$

CONCLUSION. RIC recruits the vagal anti-inflammatory reflex, which requires intact 
medRxiv preprint doi: https://doi.org/10.1101/2021.01.28.21249488; this version posted January $28,2021$. The copyright holder for this preprint (which was not certified by peer review) is the author/funder, who has granted medRxiv a license to display the preprint in It is made available under a CC-BY-NC-ND 4.0 International license .

afferent signalling from the peripheral tissue undergoing ischaemia/reperfusion to increase vagal tone and reduce neutrophil activation.

TRIAL REGISTRATION: researchregistry6482. 
medRxiv preprint doi: https://doi.org/10.1101/2021.01.28.21249488; this version posted January $28,2021$. The copyright holder for this preprint (which was not certified by peer review) is the author/funder, who has granted medRxiv a license to display the preprint in It is made available under a CC-BY-NC-ND 4.0 International license .

Electronic devices that stimulate the vagus nerve inhibit inflammation, cytokine production and neutrophil CD11b surface expression through the cholinergic anti-inflammatory pathway.(1) The key neural substrate for this neuro-immune pathway originates from cholinergic neurons residing within the brainstem dorsal vagal motor nucleus (DVMN) that project to the celiac-superior mesenteric ganglia to increase splenic nerve activity and inhibit inflammation.(2) Acetylcholine signalling through $\alpha 7$ nicotinic acetylcholine receptors $(\alpha 7 \mathrm{nAChR})$ inhibits release of TNF $\alpha$ from splenic macrophages and suppresses F-actin polymerization, the rate-limiting step for CD11b surface expression on circulating neutrophils.(3) $\mathrm{CD} 11 \mathrm{~b}$ is a critical $\beta_{2}$-integrin regulating neutrophil adhesion to the endothelium and transmigration to sites of injury and infection.(4) Modulation of leukocyte trafficking via cholinergic signaling thus suppresses the excessive accumulation of neutrophils at inflammatory sites.(3)

DVMN neurons are also critical for remote ischaemic conditioning (RIC), $(5,6)$ which preserves cardiac tissue(7) and exercise capacity after myocardial infarction in rats(8) through time-limited, repetitive ischaemia-reperfusion in a distant limb. $(9,10)$

Chemogenetic silencing of vagal neurons prevents RIC from reducing the extent of injury after myocardial infarction.(7) Since RIC and the cholinergic anti-inflammatory pathway are both cardioprotective, (11) they appaear likely to share common neural substrate residing within DVMN.

Whilst experimental activation of the inflammatory reflex has been studied using specific vagus nerve-stimulating devices, non-invasive approaches to activate the vagal antiinflammatory reflex in humans that can be applied at scale are lacking. Laboratory data demonstrate that RIC requires intact afferent sensory innervation of the remote organ undergoing RIC. $(12,13)$ Therefore, we exploited this neurophysiologic feature to test the hypothesis that nerve blockade at the level of the brachial plexus prevents cardiac vagal 
medRxiv preprint doi: https://doi.org/10.1101/2021.01.28.21249488; this version posted January $28,2021$. The copyright holder for this preprint (which was not certified by peer review) is the author/funder, who has granted medRxiv a license to display the preprint in It is made available under a CC-BY-NC-ND 4.0 International license .

and/or anti-inflammatory effects of RIC by interrupting the afferent arm of the reflex in humans. We provide the first proof-of-concept data in humans showing that RIC recruits the vagal anti-inflammatory reflex. 
medRxiv preprint doi: https://doi.org/10.1101/2021.01.28.21249488; this version posted January 28, 2021. The copyright holder for this preprint (which was not certified by peer review) is the author/funder, who has granted medRxiv a license to display the preprint in It is made available under a CC-BY-NC-ND 4.0 International license .

\section{Methods}

Study design

We conducted an experimental cross-over study in subjects scheduled for upper limb surgery at University College London Hospitals NHS Trust. The study was conducted in accordance with the principles of the Declaration of Helsinki and approved by the London (Stanmore) Research Ethics Committee (16/LO/0634). Subjects provided written informed consent to participate, having given verbal consent at least $72 \mathrm{~h}$ before the first intervention.

\section{Inclusion/exclusion criteria}

Subjects aged $>18 \mathrm{y}$ scheduled for elective upper limb surgery requiring regional anaesthesia alone were eligible. Exclusion criteria were the presence of upper limb pathology precluding use of blood pressure cuff, previous splenectomy, a history of cardiac arrythmias and/or abnormal preoperative electrocardiogram (conduction abnormality-bundle branch block, bradyarrhythmia), allergy to local anaesthetic agents and failure to achieve loss of motor power after ultrasound guided delivery of local anaesthetic.

\section{Protocol}

Subjects first underwent RIC after brachial plexus block was established, prior to upper limb surgery $\left(\mathrm{RIC}_{\text {block }}\right.$ in text; Figure 1A). On return to hospital for outpatient follow-up at least 5 weeks after surgery, RIC was repeated in the absence of brachial plexus analgesia over the same timeframe as for the first visit (Figure 1B).

\section{Ultrasound-guided supraclavicular brachial plexus block}

All ultrasound-guided blocks were conducted by senior anaesthetic staff before surgery in a quiet dedicated procedure room (Figure 1A). Patients were positioned in a semi-sitting 
medRxiv preprint doi: https://doi.org/10.1101/2021.01.28.21249488; this version posted January $28,2021$. The copyright holder for this preprint (which was not certified by peer review) is the author/funder, who has granted medRxiv a license to display the preprint in It is made available under a CC-BY-NC-ND 4.0 International license .

position with the head turned 45 degrees to the non-operative side. Standard cardiorespiratory monitoring plus Holter monitors were applied. Peripheral intravenous access was established but no sedation was administered. Under sterile conditions, a high-frequency linear array transducer (13-6 MHz, SonoSite S-Nerve; SonoSite, Inc., Bothell, WA, USA) probe was placed over the supraclavicular fossa, parallel to the clavicle to obtain a short-axis view of the divisions of the brachial plexus and the subclavian artery, lying on the first rib. Following skin infiltration with lidocaine $1 \%$, a 22 -gauge $50 \mathrm{~mm}$ insulated echogenic needle (Pajunk, Geisingen, Germany) was guided in-plane with the ultrasound beam until the needle tip was positioned at the junction of the first rib and subclavian artery; $20 \mathrm{ml} 0.5 \%$ bupivacaine was injected using a single-injection technique, with intermittent aspiration under constant ultrasound visualisation. If paraesthesia developed, the needle tip was repositioned. After completion of the block, patients remained fully monitored until their transfer to the operating room. Assessment of sensory and motor blocks was performed by one of the investigators (SK, EC, SM, GM, AR) every 5 min after local anaesthetic injection. Inability of the anaesthetised arm to overcome gravity was required prior to beginning RIC.

Upper limb remote ischaemic preconditioning.

Three cycles of ischaemia/reperfusion were performed, by inflating a $12 \mathrm{~cm}$ wide blood pressure cuff over the upper arm for 3 minutes above the systolic blood pressure to occlude the brachial artery before cuff deflation for 5 minutes (Figure 1).

\section{Heart rate analysis}

Three lead electrocardiogram recordings were captured using Lifecard CF digital Holter monitors (Spacelabs Healthcare, Hertford, UK), with a sampling rate of 1024Hz. R-R intervals from ECG data were analysed after data cleaning. Heart rate variability (HRV) 
medRxiv preprint doi: https://doi.org/10.1101/2021.01.28.21249488; this version posted January 28, 2021. The copyright holder for this preprint (which was not certified by peer review) is the author/funder, who has granted medRxiv a license to display the preprint in It is made available under a CC-BY-NC-ND 4.0 International license .

analysis from the final 5 minute segments within each recording periods by analysers masked to the intervention (Figure 1), in accord with Taskforce guidelines.(14) Serial changes in cardiac autonomic activity were quantified using three established measures of autonomic modulation of heart rate; time domain, frequency domain and non-linear analyses (Kubios HRV Premium software, Version 3.1.0, Kuopio, Finland)(15), as described previously.(16) For time-domain measures, we analysed RR interval , minimum and maximum heart rates. We performed spectral analysis using the parametric autoregressive method (AR) because it produces a spectrum with better resolution when short data frames are used and the spectrum can be divided into independent components.(17) We used high frequency $(0.15-0.4 \mathrm{~Hz})$ power spectral analysis of R-R interval time series (AR spectrum), as a measure of cardiac vagal activity.(14) Low frequency $(0.04-0.15 \mathrm{~Hz})$ power spectral analysis was also assessed as a measure of arterial baroreflex sensitivity.(18) We also examined detrended fluctuation non-linear analysis correlation measures, in which a series of RR intervals are integrated and are divided into a series of regular intervals. For each interval the fluctuation of the data from a straight line of linear interpolation is calculated. We examined changes in DFA $\alpha 1$, the values of which increase with pharmacologic (atropine) vagal blockade and decrease with sympathetic blockade.(19)

\section{Flow cytometry}

Whole blood was collected from patients who consented to repeat blood draws in BD Vacutainer ${ }^{\circledR}$ sodium citrate tubes (Becton Dickinson, UK) before the first ten-minute period of heart rate recording and at the end of the final ten-minute period of heart rate recording. To determine whether vagal activation by RIC may modulate acute inflammation, we examined whether the presence - or absence- of brachial plexus block altered myeloid (neutrophil, monocyte) cell activation after the incubation with lipopolysaccharide (LPS). Samples were 
medRxiv preprint doi: https://doi.org/10.1101/2021.01.28.21249488; this version posted January 28, 2021. The copyright holder for this preprint (which was not certified by peer review) is the author/funder, who has granted medRxiv a license to display the preprint in It is made available under a CC-BY-NC-ND 4.0 International license .

incubated with, or without, low dose of LPS (10 $\mathrm{\eta g} \mathrm{ml}^{-1}$; Escherichia coli endotoxin, serotype O111:B4, Sigma) at $37^{\circ} \mathrm{C}$ for 2 hours with gentle agitation. Immediately before the start of the protocol, and 10 minutes after the final RIC cycle, $100 \mu 1$ whole blood samples were immediately stained as described in Supplementary data (including gating strategy and antibodies used). Analysis was performed by investigators masked to the intervention. Neutrophils and monocytes were identified using forward and side scatter characteristics (Supplementary figure 1), in combination with specific cell surface antigen for CD16 (clone VEP13), CD14 (clone TUK4), respectively (Miltenyi Biotec, Germany). Co-expression of surface CD11b, CD182 [CXCR2], HLA-DR (Miltenyi Biotec, Germany) were quantified, using frequency-minus-one and appropriate isotype controls. Acquired data (BD LSRFortessa) were analyzed using FlowJo (BD Biosciences, Oxford, UK) software.

\section{Statistical Analysis}

Manual and automated validation checks of data were undertaken. Categorical data are summarised as absolute values (percentage). Continuous data are presented as mean (SD), or median [IQR], unless stated otherwise. Repeated-measures analysis of variance was used to compare heart rate and heart rate variability measures before and after RIC, taking into account each subject, timepoint and intervention (RIC with/without nerve block). Individual comparisons between groups were calculated using post-hoc Tukey-Kramer tests. Statistical analyses were undertaken using NCSS 2020 (Kaysville, UT, USA).

\section{Sample size calculation}

With a predicted resting heart rate $80 \pm 10 \mathrm{bpm}$, we estimated that a $10 \mathrm{bpm}$ difference (SD:10bpm) between RIC with versus without upper limb block would require at least 15 individuals to be recruited $(\alpha=0.01 ; 1-\beta=0.9)$. Allowing for $25 \%$ drop-out rate (including 
medRxiv preprint doi: https://doi.org/10.1101/2021.01.28.21249488; this version posted January $28,2021$. The copyright holder for this preprint (which was not certified by peer review) is the author/funder, who has granted medRxiv a license to display the preprint in It is made available under a CC-BY-NC-ND 4.0 International license .

failure to re-attend for the follow-up protocol), the estimated sample size was initially increased to 30 subjects but revised to 20 subjects having established $>90 \%$ follow-up rate from the first 10 participants. 
medRxiv preprint doi: https://doi.org/10.1101/2021.01.28.21249488; this version posted January 28, 2021. The copyright holder for this preprint (which was not certified by peer review) is the author/funder, who has granted medRxiv a license to display the preprint in It is made available under a CC-BY-NC-ND 4.0 International license .

\section{Results}

\section{Subject characteristics}

A minority of the participants were taking any regular cardiovascular medications. None had a clinical history of ischaemic heart disease. The single subject requiring oral medication for diabetic control did not have any clinical evidence for pre-existing neuropathy (Table 1). Most subjects were undergoing elective upper limb surgery for long-standing orthopaedic indications, rather than inflammatory arthropathy. Repeat blood samples were obtained from nine patients who consented to repeat sampling.

\section{Time domain measures of heart rate variability}

RR-interval did not change after $\mathrm{RIC}_{\text {block }}$ (mean difference:20ms (95\%CI:-11 to 50), $\mathrm{P}=0.19$ ). RIC increased RR-interval (i.e. slowed heart rate) by 40ms (95\% confidence intervals (95\%CI):13-66). (Figure 3A). In the presence of brachial plexus block, minimum RRinterval after RIC did not change (mean difference:26ms (95\%CI:-20 to 72); $\mathrm{P}=0.24$ ) (Figure 3B). RIC increased minimum RR-interval by 39ms (95\% CI:3-74); $\mathrm{P}=0.03$ ). Similarly, after $\mathrm{RIC}_{\text {block}}$, maximum RR-interval remained unchanged (mean difference:12ms (-20 to 41); $\mathrm{P}=0.43$; Figure 3C). Maximum RR-interval increased after RIC by $28 \mathrm{~ms}$ (95\% CI:-2 to 58); $\mathrm{P}=0.06$ ). Other time-domain measures of $\mathrm{HRV}$ were similar between RIC and RIC block (Supplementary figure 2).

\section{Frequency-domain measures of heart rate variability}

Low frequency (LF) band peak frequency (autoregressive spectrum) did not change after RIC, but in the presence of brachial plexus block RIC resulted in increased LF component of HRV (Figure 4A). In the absence of neural block, RIC had no effect on the high-frequency 
medRxiv preprint doi: https://doi.org/10.1101/2021.01.28.21249488; this version posted January 28, 2021. The copyright holder for this preprint (which was not certified by peer review) is the author/funder, who has granted medRxiv a license to display the preprint in It is made available under a CC-BY-NC-ND 4.0 International license .

(HF) vagal modulatory component of HRV (Figure 4B). In the presence of brachial plexus block, $\mathrm{HF}$ was reduced (intervention $\mathrm{x}$ timepoint: $\left.F_{(3,3.26)} \mathrm{P}=0.03\right)$.

\section{Non-linear analysis of heart rate variability}

The detrended fluctuation analysis measure DFA $\alpha 1$ increased after $\mathrm{RIC}_{\text {block }}(0.124$ (95\% confidence intervals:0.01-0.24); $\mathrm{P}=0.039)$, indicative of reduced vagal tone. In the absence of brachial plexus block, DFA $\alpha 1$ remained unchanged after RIC (Figure 5).

\section{Neutrophil activation following RIC}

Repeat blood samples were obtained from nine patients who consented to repeat sampling. Before establishing brachial plexus blockade (Figure 6A), expression of CD11b on neutrophils increased after incubation with LPS in whole blood (mean difference in median fluorescence intensity (MFI): 19 (95\%CI:9-28); P=0.001; post-hoc Tukey-Kramer test). After establishing brachial plexus blockade, expression of CD11b on neutrophils remained similar ( $\mathrm{P}=0.72$; Supplementary figure 3 ). RIC after establishing brachial plexus blockade attenuated the LPS-induced increase in CD11b expression (mean difference in MFI: 9 (95\%CI:-1 to 19; $\mathrm{P}=0.08$; post-hoc Tukey-Kramer test). When subjects returned six weeks later to undergo RIC alone, LPS again increased surface expression (median fluorescence intensity) of CD11b on CD16 ${ }^{+}$neutrophils by 31 units (95\%CI:25-38); P<0.001; post-hoc Tukey-Kramer test) (Figure 6A). RIC had no effect on CD16CD11b expression (mean difference:-3 (95\%CI:-10 to 3); $\mathrm{P}=0.41)$. After RIC, the effect of LPS on surface expression of CD11b on neutrophils was reduced, compared to the effect of LPS before RIC (mean difference:12 arbitrary units (95\%CI:5-18); P=0.002; post-hoc Tukey-Kramer test). CXCR2 expression on neutrophils, which mediates massive cardiac neutrophil infiltration after myocardial infarction,(20) was similar between RIC and RIC $_{\text {block. CXCR2 expression on }}$ 
medRxiv preprint doi: https://doi.org/10.1101/2021.01.28.21249488; this version posted January $28,2021$. The copyright holder for this preprint (which was not certified by peer review) is the author/funder, who has granted medRxiv a license to display the preprint in It is made available under a CC-BY-NC-ND 4.0 International license .

neutrophils after incubation with LPS were similar in the presence, or absence, of brachial plexus blockade (Figure 6D).

\section{Monocyte activation}

Before establishing brachial plexus blockade prior to RIC, LPS increased surface expression of $\mathrm{CD} 11 \mathrm{~b}$ on $\mathrm{CD} 14^{+}$monocytes (mean difference:9 (95\%CI:1-18); P=0.04; Figure 6B). RIC had no effect on $\mathrm{CD} 14^{+} \mathrm{CD} 11 \mathrm{~b}$ expression (mean difference:-1 (95\%CI:-25 to 23); $\mathrm{P}=0.98$ ). After RIC, LPS had no effect on surface expression of CD11b on monocytes (mean difference:-7 arbitrary units (95\%CI:-30 to 17); $\mathrm{P}=0.73$ ). When subjects returned six weeks later to undergo RIC alone, LPS increased surface expression of CD11b on monocytes before RIC was implemented (by 17 arbitrary units (95\%CI:7-28); P=0.001; post-hoc Tukey-Kramer test; Figure 6A). After RIC, LPS failed to increase surface expression of CD11b (mean difference:-5 (95\%CI:-16 to 5); $\mathrm{P}=0.38$; post-hoc Tukey-Kramer test). The presence or absence of brachial plexus block had no effect on LPS-evoked increases in HLA-DR expression on $\mathrm{CD}_{14}{ }^{+}$monocytes (Figure 6C). LPS evoked a similar increase in HLA-DR after RIC (39 (95\%CI:27-52); P<0.001), but this response was similar in magnitude to the effect seen before RIC (mean difference:4 arbitrary units (95\%CI:-8 to 17); $\mathrm{P}=0.71$ ). 
medRxiv preprint doi: https://doi.org/10.1101/2021.01.28.21249488; this version posted January 28, 2021. The copyright holder for this preprint (which was not certified by peer review) is the author/funder, who has granted medRxiv a license to display the preprint in It is made available under a CC-BY-NC-ND 4.0 International license .

\section{Discussion}

This study demonstrates that RIC preserves cardiac vagal activity through afferent signalling from the organ/tissue undergoing RIC, as measured by three independent measures of heart rate variability. When neural transmission from ischaemic tissue was prevented by brachial plexus block using local anaesthesia, vagal activity was reduced. Acute inflammation elicited ex-vivo by LPS augmented markers of myeloid activation following brachial plexus block, but this inflammatory response was reduced by RIC when afferent signalling from the ischaemic tissue was intact.

A role for neural afferents in RIC has been suggested in experimental models in which peripheral nociception induced by skin incisions on the abdomen provided cardioprotection in mice.(13) Topical application of $0.1 \%$ capsaicin cream on the abdomen or paw before myocardial ischaemia/reperfusion (6) (12) reduced infarct size in rodents via neurogenic signaling involving spinal nerves, sympathetic nerves, and activation of PKC $\varepsilon$ in the heart. (13) Similarly, chronic neuropathic pain activates neurons within the anterior nucleus of paraventricular thalamus, which increases release of acetylcholine via the vagus nerve activity to trigger PKC $\varepsilon$-mediated cardioprotection following ischemia-reperfusion injury.(21) Pharmacological inhibition of extracellular signal-regulated kinase activation in the PVA abolishes neuropathic pain-induced cardioprotection, whereas pharmacologic or optogenetic activation of PVA neurons confers cardioprotection.(21) By extension, patients with established peripheral neuropathy (e.g. those with diabetes mellitus), $(22,23)$ or who acquire loss of vagal activity (e.g. central neuromodulatory effects of general anaesthesia),(16, 24) are therefore not likely to benefit from RIC.

We used three measures of heart rate variability to dissect the autonomic components contributing to RIC. The 10 minute recording period at the start and end of each protocol enabled sufficient time to capture high quality ECG data for the analysis. Frequency domain 
medRxiv preprint doi: https://doi.org/10.1101/2021.01.28.21249488; this version posted January 28, 2021. The copyright holder for this preprint (which was not certified by peer review) is the author/funder, who has granted medRxiv a license to display the preprint in It is made available under a CC-BY-NC-ND 4.0 International license .

and non-linear analyses strongly suggested that parasympathetic activation is a key feature of RIC, being independent of underlying changes in heart rate.(25) We performed spectral analysis using the parametric autoregressive method (AR) because it produces a spectrum with superior resolution using shorter data frames.(26) We used HF as an index of vagal modulation of heart rate, which is abolished under conditions of vagal blockade.(17) RIC alone preserved the high frequency power band whereas HF declined after RIC in the presence of brachial plexus block, suggesting neural afferent activity is required to maintain parasympathetic activity. In support of this, the non-linear measure DFA, which most closely corresponds to short-term fluctuations, increased after RIC following brachial plexus block. Given that DFA $\alpha 1$ was preserved in the absence of brachial plexus block, these data suggest that RIC initiates vagal activation since DFA $\alpha 1$ increases with vagal blockade and decreases with sympathetic blockade.(19)

The rapid effect of RIC in conferring cardioprotection - over minutes- led us to focus primarily on circulating myeloid cells. As the archetypal first responders to acute inflammation and injury, neutrophils are activated rapidly. Neutrophil depletion reduces tissue injury after myocardial ischemia-reperfusion in both patients(27) and animal models of myocardial ischaemia-reperfusion.(28) However, dysregulated, persistent and/or overexuberant leukocyte recruitment to ischaemic tissue can fuel excessive inflammation and exacerbate further tissue injury.(29) Our findings are the first to provide human data in support of a direct link between preserved efferent vagal activity and neutrophil responses to ischaemic-reperfusion injury. The surface receptor integrin $\mathrm{CD} 11 \mathrm{~b} / \mathrm{CD} 18$ serves as a pattern recognition receptor on phagocytes, including neutrophils, to recognize pathogen and damage-associated molecular patterns.(30) A specific anti-CD18 monoclonal antibody reduces polymorphonuclear cell-mediated contractile dysfunction in an in vitro model of 
medRxiv preprint doi: https://doi.org/10.1101/2021.01.28.21249488; this version posted January $28,2021$. The copyright holder for this preprint (which was not certified by peer review) is the author/funder, who has granted medRxiv a license to display the preprint in It is made available under a CC-BY-NC-ND 4.0 International license .

myocardial ischemia-reperfusion injury by limiting polymorphonuclear cell accumulation.(31)

RIC failed to prevent LPS-induced downregulation of CXCR2 and increased expression of monocyte HLA-DR. Our observations are consistent with laboratory models exploring the vagal anti-inflammatory reflex, which demonstrated a reduction, rather than complete suppression, of the inflammatory response to a range of DAMPs and PAMPs.(32) Nicotinic cholinergic receptors provide the neuroimmune receptor mediated link between myeloid cells and preserved vagal activity.(33) Unstimulated neutrophils isolated from human blood express $\alpha 7 \mathrm{nAChRs}$ and $\alpha 3 \beta 4$ nAChRs.(34) Nicotine, an agonist of the $\alpha 7$ AChR mediated vagal anti-inflammatory pathway in macrophages, reduces levels of CD11b on the surface of neutrophils in a dose-dependent manner by suppressing F-actin polymerization, the rate-limiting step for CD11b surface expression.(3) As with macrophages, vagus nerve stimulation attenuates neutrophil surface CD11b levels only in the presence of an intact and innervated spleen.(3) Reduced expression of CD11b, which also serves as a receptor for complement $\mathrm{C} 3 \mathrm{~b}$, limits cell-mediated cytotoxicity, chemotaxis and phagocytosis.

A rapid decline in the surface expression of HLA-DR is observed on monocytes obtained from patients after acute myocardial infarction.(35) Circulating CD14 ${ }^{+} \mathrm{HLA}-$ $\mathrm{DR}^{\text {neg/low }}$ monocytes secrete high levels of TNF $\alpha$, IL-6, and IL-1ß which promote proinflammatory immune responses; in the expansion of this monocyte population after myocardial infarction correlates with both cardiac damage and physiological function.(36) However, RIC had no effect on CD14 ${ }^{+}$HLA-DR surface expression either in the presence, or absence, of brachial plexus block. Similarly, expression of the chemokine receptor CXCR2, deficiency of which limits neutrophil recruitment and the extent of myocardial infarction size, was not altered by RIC in the presence or absence of brachial plexus block. 
medRxiv preprint doi: https://doi.org/10.1101/2021.01.28.21249488; this version posted January $28,2021$. The copyright holder for this preprint (which was not certified by peer review) is the author/funder, who has granted medRxiv a license to display the preprint in It is made available under a CC-BY-NC-ND 4.0 International license .

Several randomised clinical trials, particularly in elective cardiac surgery, have failed to show consistent benefits of RIC on clinical outcomes.(37) Our study provides direct human translational data supporting laboratory findings demonstrating that autonomic modulation contributes to the downstream biologic effects of RIC. Bidirectional feedback mechanisms between the heart and the brain require both neural and humoral pathways for effective RIC.(38) The frequency and ease with which the autonomic component of RIC may be disrupted is likely to account for the results in several neutral trials. For example, peripheral neuropathy in patients with diabetes mellitus and metabolic syndrome is common.(39) Markedly reduced vagal activity is common in individuals who are physically deconditioned.(40-42) Furthermore, neural processing in autonomic pathways within the central nervous system is profoundly disrupted by anaesthetic agents. $(43,44)$

The development of this human model enabled each subject to serve as their own control while remaining masked to laboratory-based outcomes. Capturing both autonomic and immunologic readouts added further complementary data to address the central hypothesis that RIC preserves and/or stimulates vagal activity RIC. We were unable to randomise the sequence of block versus control RIC, as subjects gave consent prior to elective upper limb surgery. Similarity in both autonomic and inflammatory measures at the start of both control and block protocols suggest that the impact of randomising the sequence of interventions would not be significant. Brachial plexus nerve block is not a minor procedure for subjects who do not require surgery, hence the choice of participants were preoperative patients. It is important to highlight that ultrasound-guided brachial plexus block was undertaken without sedation, which alters autonomic function.(45) Although data were captured only during the protocol period, we have established that this model of brachial plexus block serves as a potentially useful tool over the longer term to further dissect mechanisms of RIC in humans. 
medRxiv preprint doi: https://doi.org/10.1101/2021.01.28.21249488; this version posted January $28,2021$. The copyright holder for this preprint (which was not certified by peer review) is the author/funder, who has granted medRxiv a license to display the preprint in It is made available under a CC-BY-NC-ND 4.0 International license .

In summary, we have shown, for the first time in humans, that RIC requires an afferent neural component to preserve vagal and recruit anti-inflammatory mechanisms previously identified in laboratory animal models. Closing this translational gap in mechanistic knowledge in humans explains, in part, the variable effect of RIC in conferring cardiac and renal protection.(38) Our data suggest that a personalised medicine approach may benefit individuals who are capable of mounting an integrated innate protective reflexes in response to RIC. 
medRxiv preprint doi: https://doi.org/10.1101/2021.01.28.21249488; this version posted January $28,2021$. The copyright holder for this preprint (which was not certified by peer review) is the author/funder, who has granted medRxiv a license to display the preprint in It is made available under a CC-BY-NC-ND 4.0 International license .

\section{Table 1. Subject characteristics}

Data is presented as mean with standard deviations (SD) for parametric data and as median (25th-75th interquartile range) for non-parametric data. Frequencies are presented with percentages $(\%)$. Age is rounded to the nearest year. ACE-I: Angiotensin converting enzyme inhibitor. ARB: angiotensin receptor blocker.

\begin{tabular}{|l|l|}
\hline Age (y) & $56(36-61)$ \\
\hline Female sex (n;\%) & $9(52.9 \%)$ \\
\hline Co-morbidities (n; \%) & \\
\hline Asthma & $5(29.4 \%)$ \\
\hline Atherosclerotic cardiovascular disease & 0 \\
\hline Diabetes mellitus & $1(5.9 \%)$ \\
\hline Current smoker & $4(23.5 \%)$ \\
\hline Hypertension & $2(11.8 \%)$ \\
\hline Active cancer & $0(56.1 \%)$ \\
\hline Inflammatory arthritis & $4(23.5 \%)$ \\
\hline At least one cardiovascular medication (n; \%) & $4(23.5 \%)$ \\
\hline Beta blocker & $1(5.9 \%)$ \\
\hline Calcium channel blocker & $1(5.9 \%)$ \\
\hline Diuretic & $1(5.9 \%)$ \\
\hline Statin & $1(5.9 \%)$ \\
\hline ARB/ACE-I & 0 \\
\hline Nitrate & $1(5.9 \%)$ \\
\hline NSAIDs & $2(11.8 \%)$ \\
\hline Opioids & $1(5.9 \%)$ \\
\hline Antidepressant & 0 \\
\hline Steroid/immunosuppresant & \\
\hline
\end{tabular}


medRxiv preprint doi: https://doi.org/10.1101/2021.01.28.21249488; this version posted January 28, 2021. The copyright holder for this preprint (which was not certified by peer review) is the author/funder, who has granted medRxiv a license to display the preprint in It is made available under a CC-BY-NC-ND 4.0 International license .

\section{Figure Legends}

\section{Figure 1. Experimental design}

Sequence of experimental procedures for RIC undertaken in presence and absence of brachial plexus block. 10 minute recording sessions are indicated by clear bars. Three cycles of ischaemia (applied for 3 minutes) followed by 5 minutes of reperfusion were applied. Blood samples were obtained at the times indicated by the collection bottles.

A. For the first visit, brachial plexus block with ultrasound guided injection of local anaesthetic was undertaken.

B. For the return visit, a time-matched protocol was followed without brachial plexus block before three cycles of RIC were undertaken.

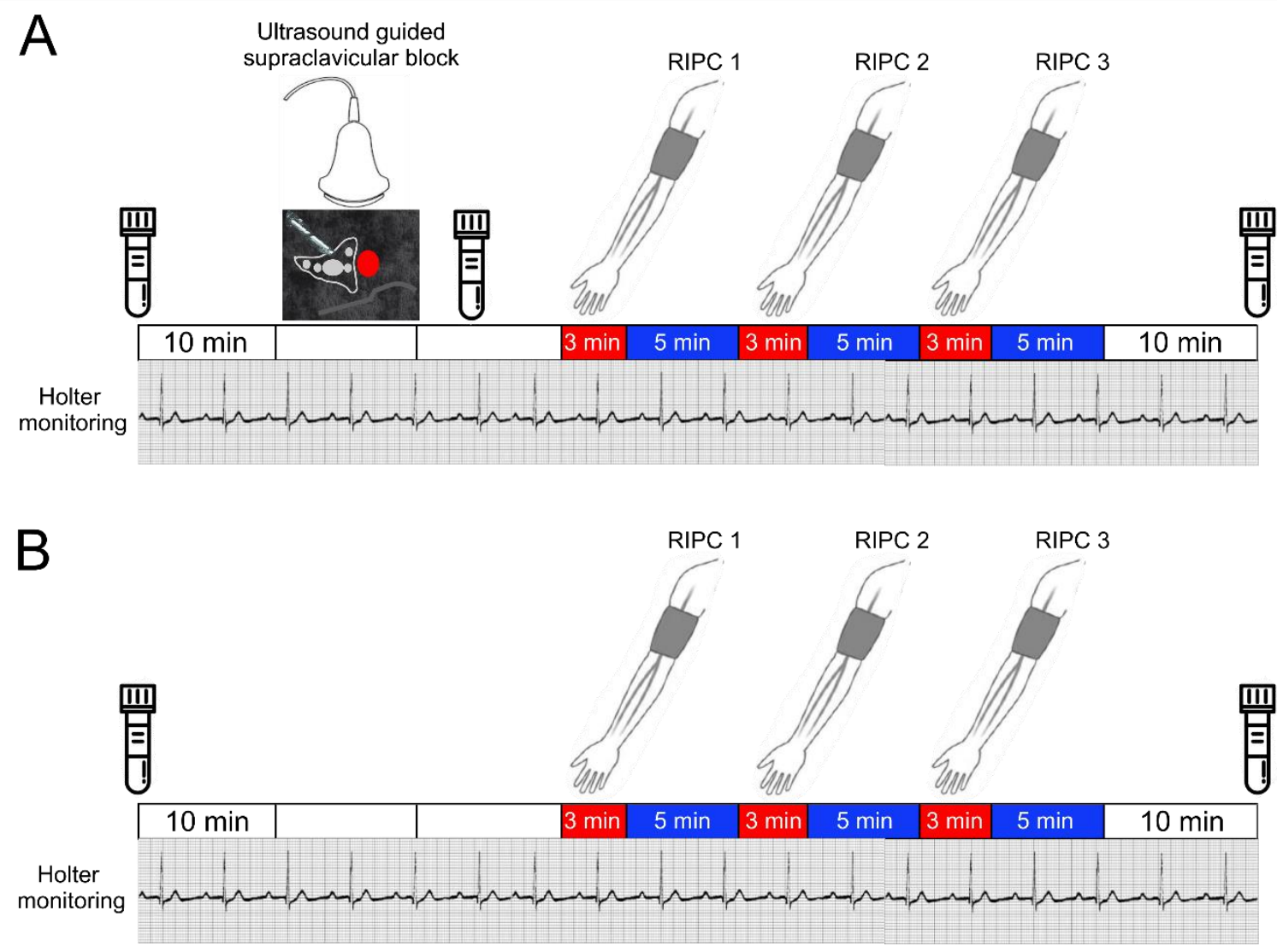


medRxiv preprint doi: https://doi.org/10.1101/2021.01.28.21249488; this version posted January 28, 2021. The copyright holder for this preprint (which was not certified by peer review) is the author/funder, who has granted medRxiv a license to display the preprint in It is made available under a CC-BY-NC-ND 4.0 International license .

\section{Figure 2. CONSORT diagram}

Screening, enrolment and follow up data for study, in accord with CONSORT requirements.

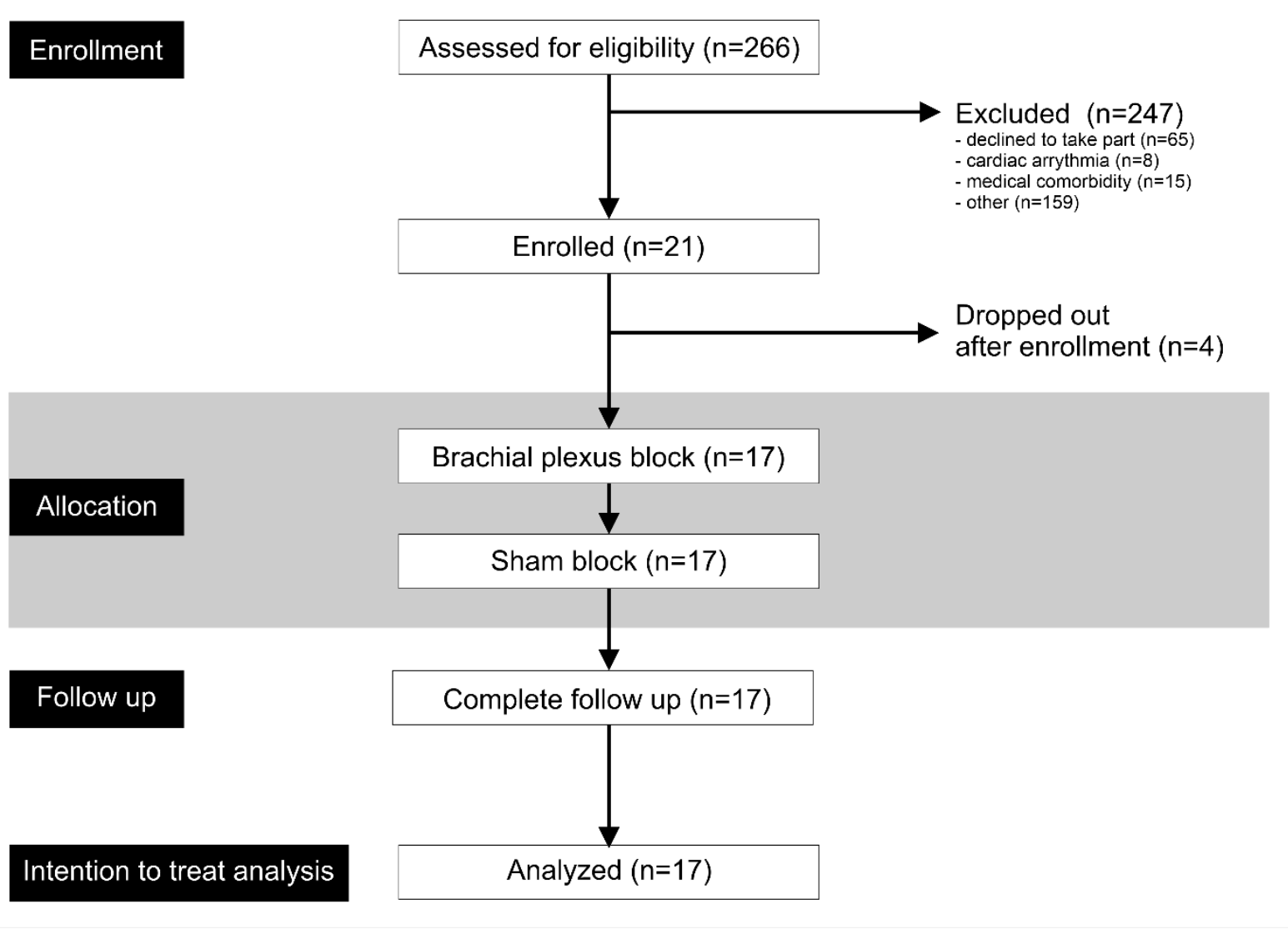


medRxiv preprint doi: https://doi.org/10.1101/2021.01.28.21249488; this version posted January 28, 2021. The copyright holder for this preprint (which was not certified by peer review) is the author/funder, who has granted medRxiv a license to display the preprint in It is made available under a CC-BY-NC-ND 4.0 International license .

Figure 3. Heart rate changes before and after RIC in same individuals with/without brachial plexus block.

Pre-data point for each experiment refers to final 5 minutes of data recorded within 10 minute period before brachial plexus block was performed. Post refers to final 5

minutes of data recorded within 10 minute time period following the final 5 minute washout period of the third cycle of RIC.

A. Individual datapoints for mean R-R interval in the presence, and absence, of brachial plexus block, during pre and postRIC recording periods.

B. Individual datapoints for minimum heart rate achieved in the presence, and absence,

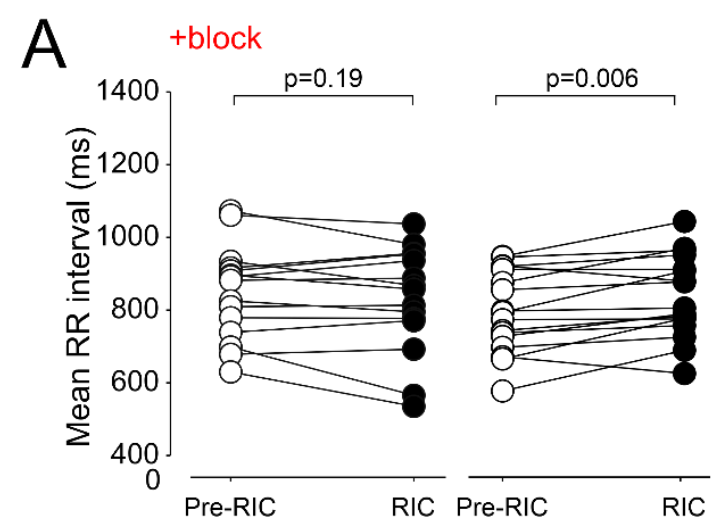

B +block

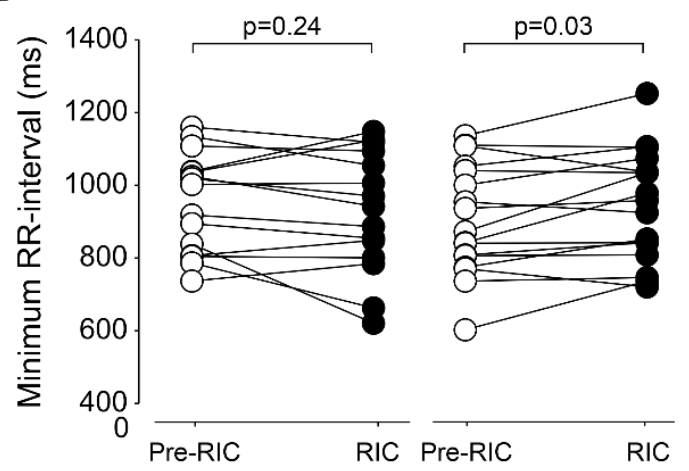
of brachial plexus block, during pre and

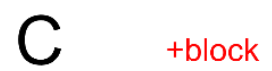
post-RIC recording periods., $\mathrm{p}$ values comparing pre versus post values (repeated-measures analysis of variance), post-hoc Tukey-Kramer test.

C. Individual datapoints for maximum

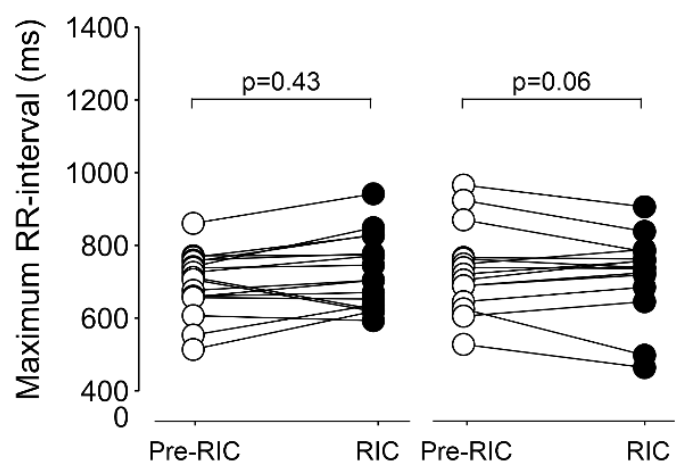
heart rate achieved in the presence, and absence, of brachial plexus block, during pre and post-RIC recording periods. $\mathrm{p}$ values comparing pre versus post values (repeated-measures analysis of variance), post-hoc Tukey-Kramer test. 
medRxiv preprint doi: https://doi.org/10.1101/2021.01.28.21249488; this version posted January 28, 2021. The copyright holder for this preprint (which was not certified by peer review) is the author/funder, who has granted medRxiv a license to display the preprint in It is made available under a CC-BY-NC-ND 4.0 International license .

Figure 4. Frequency domain measures before and after RIC in same individuals with/without brachial plexus block.

A. Low frequency power.

B. High frequency power.

Mean (95\% confidence intervals) shown; values are shown for post-hoc Tukey-Kramer testing, following repeat-measures ANOVA.

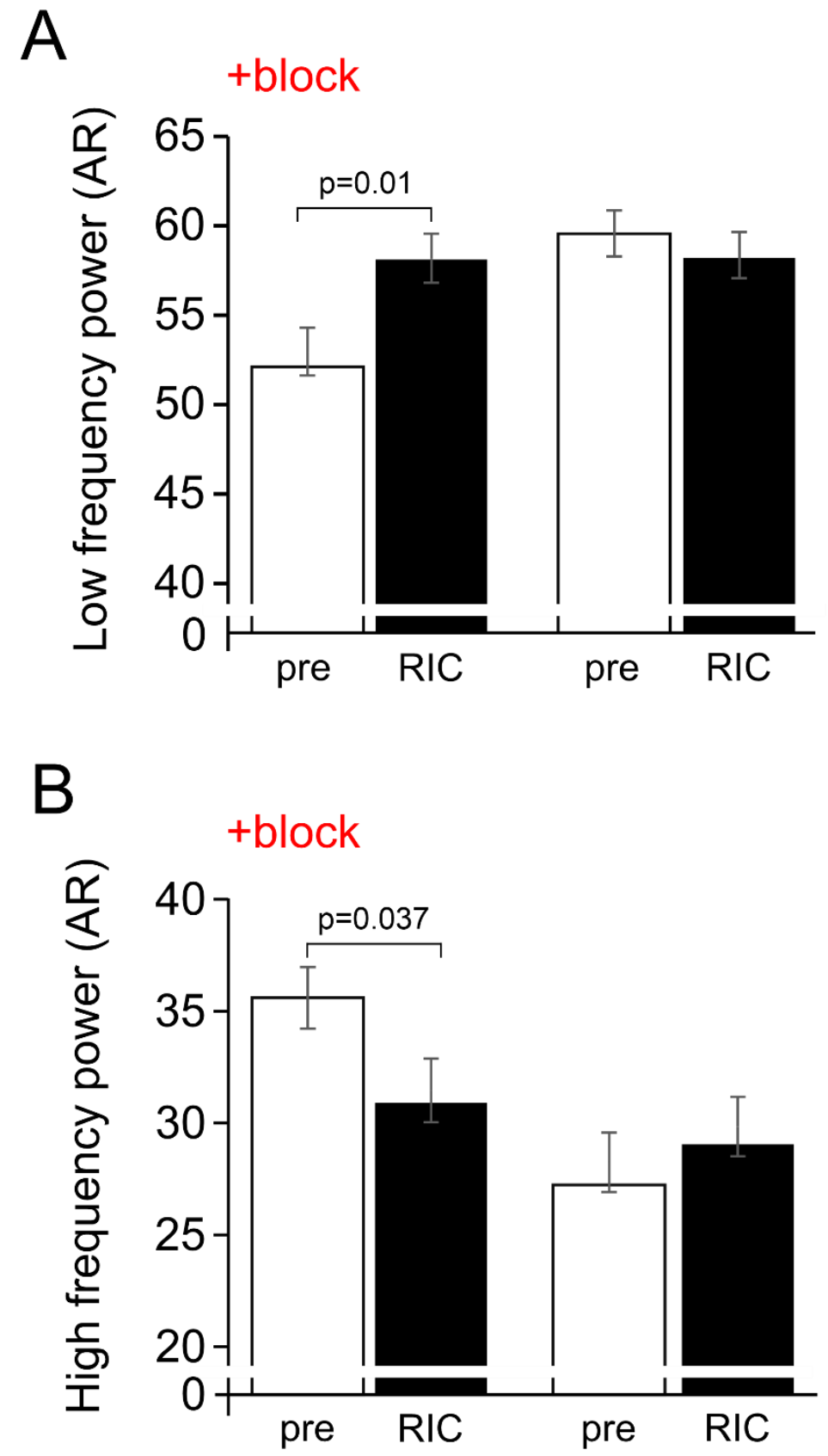


medRxiv preprint doi: https://doi.org/10.1101/2021.01.28.21249488; this version posted January 28, 2021. The copyright holder for this preprint (which was not certified by peer review) is the author/funder, who has granted medRxiv a license to display the preprint in It is made available under a CC-BY-NC-ND 4.0 International license .

Figure 5. Non-linear analysis of HRV before and after RIC in same individuals with/without brachial plexus block.

Individual datapoints for DFA in the presence, and absence, of brachial plexus block, pre and post RIC. $\mathrm{p}$ values refer to posthoc Tukey-Kramer testing, following repeat-measures ANOVA.

\section{RIC+block}

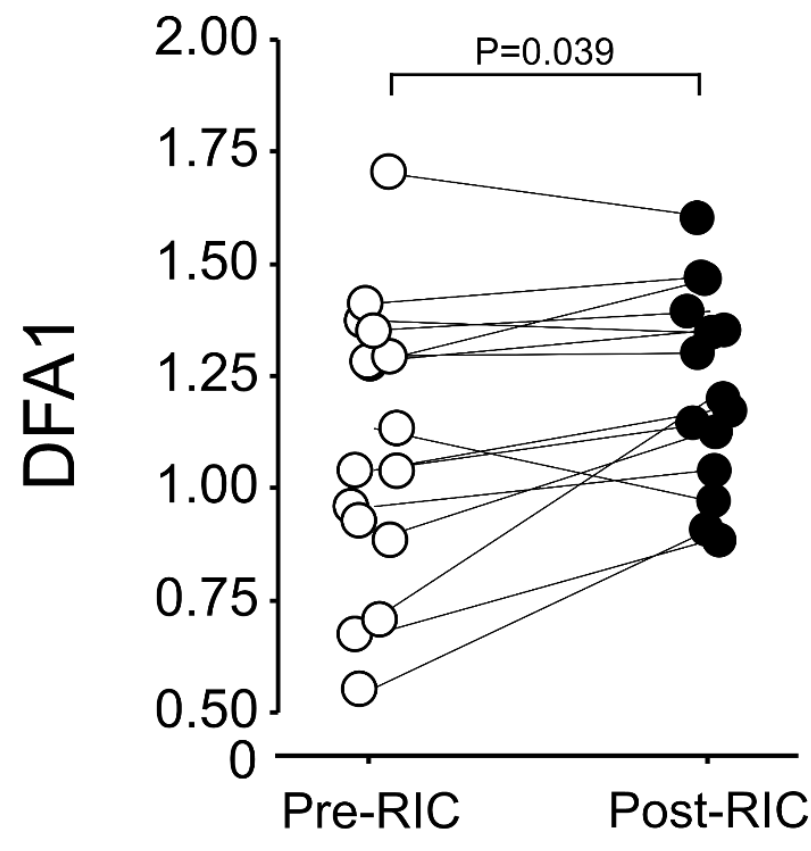

RIC alone
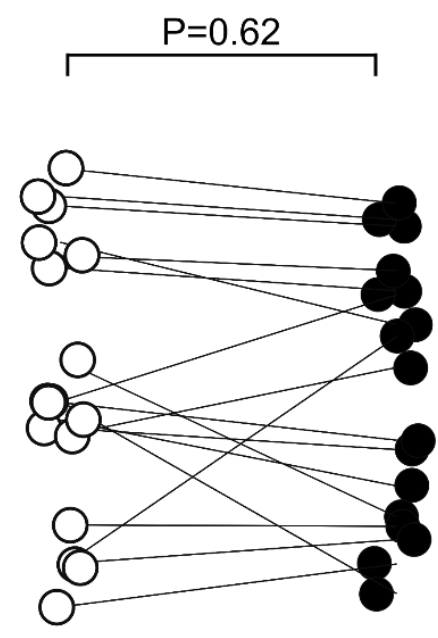

Pre-RIC
Post-RIC

Figure 6. Flow cytometry before and after RIC in seven individuals with/without brachial plexus block.

A. Surface expression of CD11b on circulating CD16 neutrophils.

B. Surface expression of CD11b on circulating CD14 monocytes.

C. Surface expression of HLA-DR on circulating CD14 monocytes.

D. Surface expression of CXCR2 (CD182) on circulating CD16 neutrophils.

$\mathrm{P}$ values are shown for post-hoc Tukey-Kramer testing (RIC/pre RIC versus LPS/saline control). 
medRxiv preprint doi: https://doi.org/10.1101/2021.01.28.21249488; this version posted January 28, 2021. The copyright holder for this preprint (which was not certified by peer review) is the author/funder, who has granted medRxiv a license to display the preprint in It is made available under a CC-BY-NC-ND 4.0 International license .
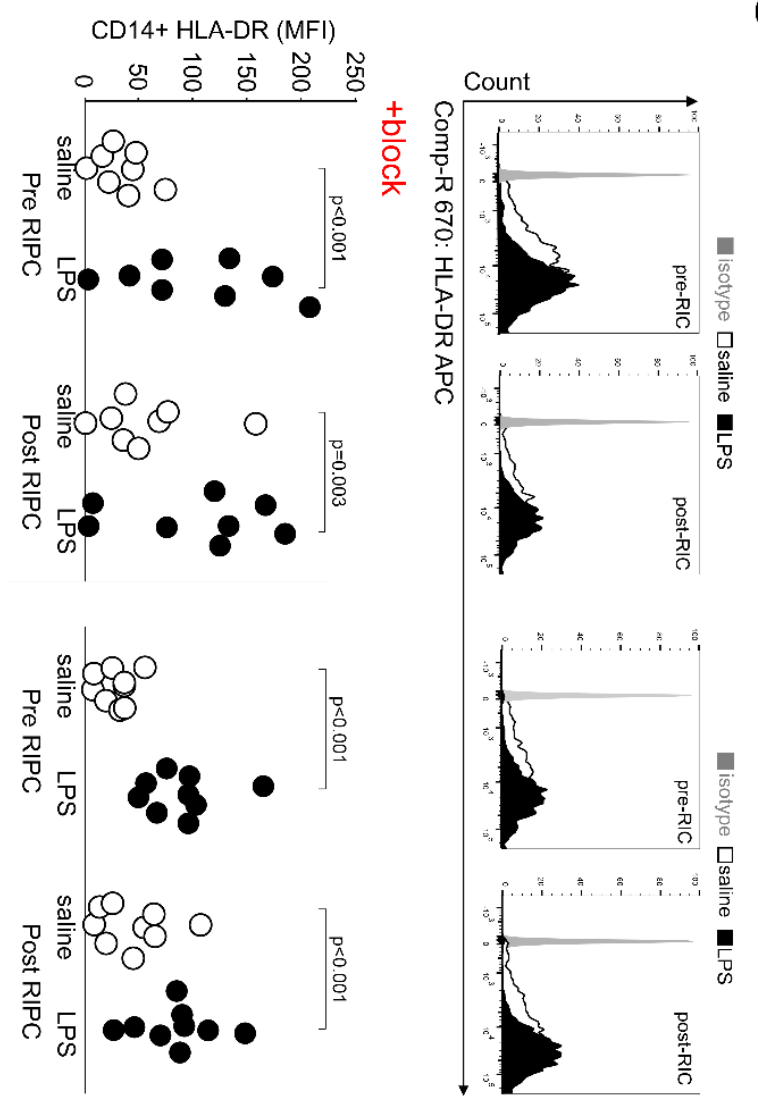

○

$\mathrm{CD} 16+\mathrm{CD} 11 \mathrm{~b}+(\mathrm{MFI})$

$>$
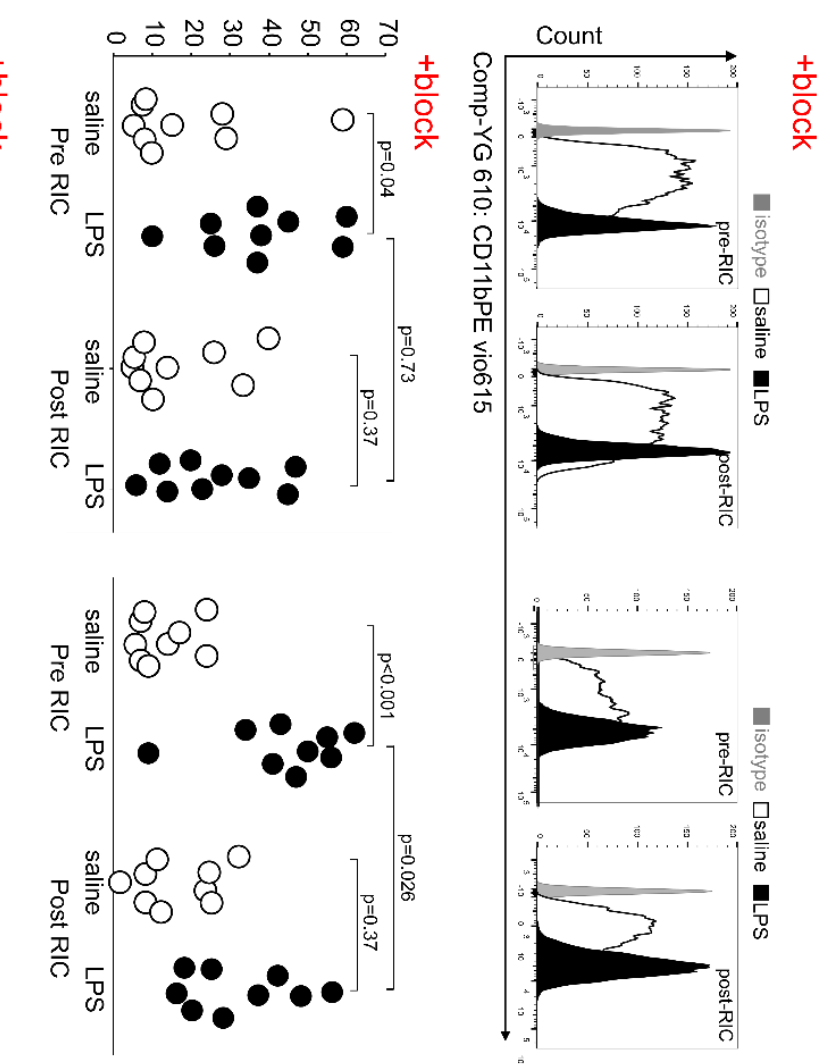

$\varpi$
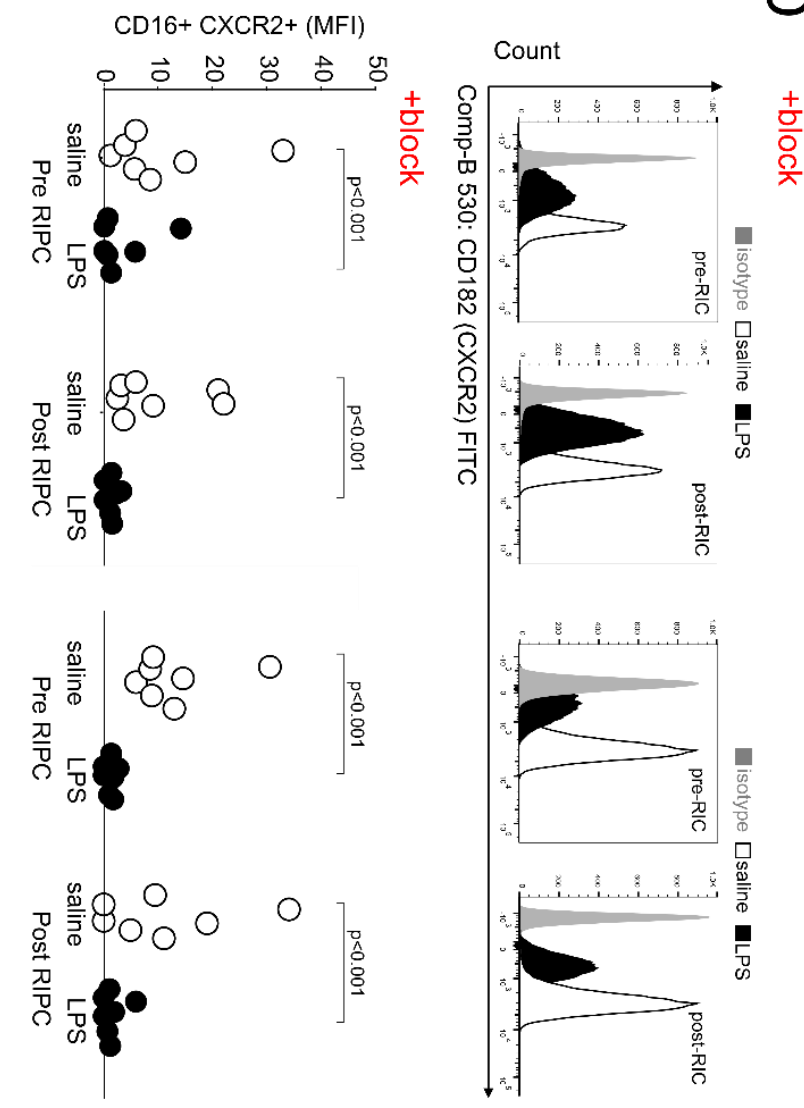

$\bigcirc \mathrm{CD} 14+\mathrm{CD} 11 \mathrm{~b}+(\mathrm{MFI})$
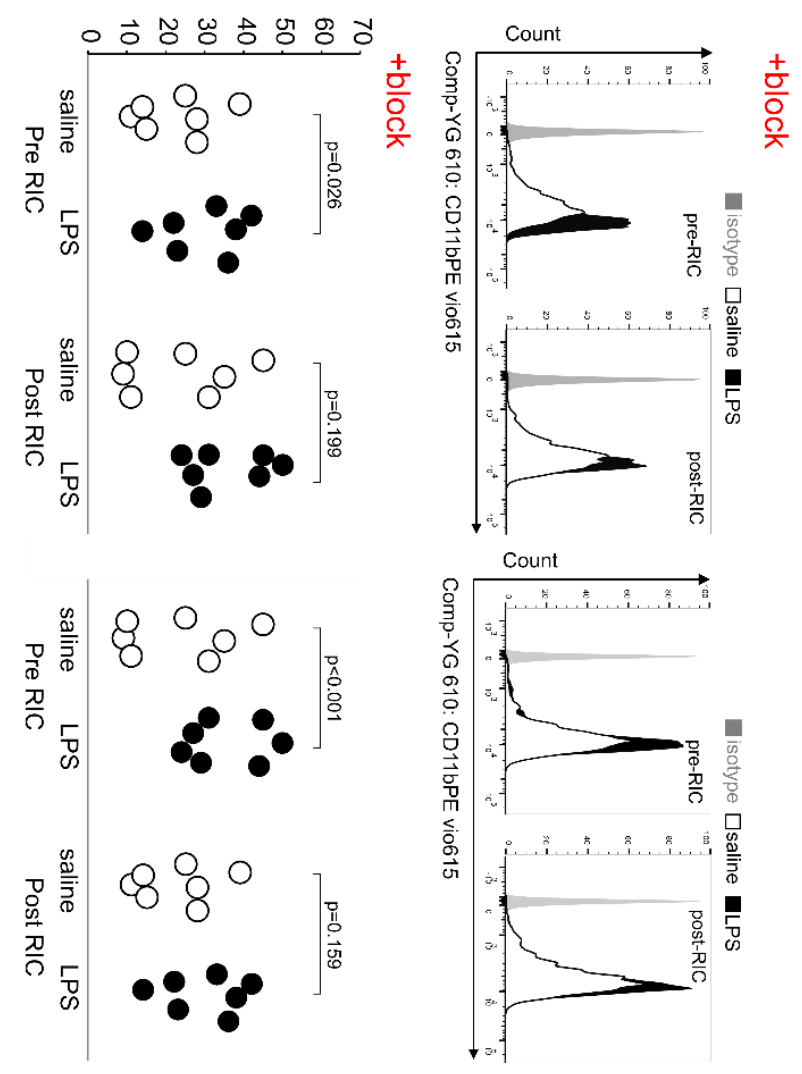
medRxiv preprint doi: https://doi.org/10.1101/2021.01.28.21249488; this version posted January 28, 2021. The copyright holder for this preprint (which was not certified by peer review) is the author/funder, who has granted medRxiv a license to display the preprint in It is made available under a CC-BY-NC-ND 4.0 International license .

\section{References}

1. Chavan SS, Pavlov VA, and Tracey KJ. Mechanisms and Therapeutic Relevance of Neuroimmune Communication. Immunity. 2017;46(6):927-42.

2. Kressel AM, Tsaava T, Levine YA, Chang EH, Addorisio ME, Chang Q, et al. Identification of a brainstem locus that inhibits tumor necrosis factor. Proc Natl Acad Sci U S A. 2020;117(47):29803-10.

3. Huston JM, Rosas-Ballina M, Xue X, Dowling O, Ochani K, Ochani M, et al. Cholinergic neural signals to the spleen down-regulate leukocyte trafficking via CD11b. J Immunol. 2009;183(1):552-9.

4. Fagerholm SC, Varis M, Stefanidakis M, Hilden TJ, and Gahmberg CG. alpha-Chain phosphorylation of the human leukocyte CD11b/CD18 (Mac-1) integrin is pivotal for integrin activation to bind ICAMs and leukocyte extravasation. Blood. 2006;108(10):3379-86.

5. Lim SY, Yellon DM, and Hausenloy DJ. The neural and humoral pathways in remote limb ischemic preconditioning. Basic Res Cardiol. 2010;105(5):651-5.

6. Redington KL, Disenhouse T, Strantzas SC, Gladstone R, Wei C, Tropak MB, et al. Remote cardioprotection by direct peripheral nerve stimulation and topical capsaicin is mediated by circulating humoral factors. Basic Res Cardiol. 2012;107(2):241.

7. Mastitskaya S, Marina N, Gourine A, Gilbey MP, Spyer KM, Teschemacher AG, et al. Cardioprotection evoked by remote ischaemic preconditioning is critically dependent on the activity of vagal pre-ganglionic neurones. Cardiovasc Res. 2012;95(4):487-94.

8. Machhada A, Hosford PS, Dyson A, Ackland GL, Mastitskaya S, and Gourine AV. Optogenetic Stimulation of Vagal Efferent Activity Preserves Left Ventricular Function in Experimental Heart Failure. JACC Basic Trans/ Sci. 2020;5(8):799-810.

9. Walsh SR, Tang T, Sadat U, Dutka DP, and Gaunt ME. Cardioprotection by remote ischaemic preconditioning. Br J Anaesth. 2007;99(5):611-6.

10. Heusch G, Botker HE, Przyklenk K, Redington A, and Yellon D. Remote ischemic conditioning. J Am Coll Cardiol. 2015;65(2):177-95.

11. Wu SJ, Li YC, Shi ZW, Lin ZH, Rao ZH, Tai SC, et al. Alteration of Cholinergic Anti-Inflammatory Pathway in Rat With Ischemic Cardiomyopathy-Modified Electrophysiological Function of Heart. J Am Heart Assoc. 2017;6(9).

12. Basalay M, Barsukevich V, Mastitskaya S, Mrochek A, Pernow J, Sjoquist PO, et al. Remote ischaemic pre- and delayed postconditioning - similar degree of cardioprotection but distinct mechanisms. Exp Physiol. 2012;97(8):908-17.

13. Jones WK, Fan GC, Liao S, Zhang JM, Wang Y, Weintraub NL, et al. Peripheral nociception associated with surgical incision elicits remote nonischemic cardioprotection via neurogenic activation of protein kinase C signaling. Circulation. 2009;120(11 Suppl):S1-9.

14. Electrophysiology TFotESoCtNASoP. Heart Rate Variability: Standards of Measurement, Physiological Interpretation, and Clinical Use. Circulation Research. 1996(93):1043-65.

15. Tarvainen MP, Niskanen JP, Lipponen JA, Ranta-Aho PO, and Karjalainen PA. Kubios HRV-heart rate variability analysis software. Comput Methods Programs Biomed.

2014;113(1):210-20.

16. May SM, Reyes A, Martir G, Reynolds J, Paredes LG, Karmali S, et al. Acquired loss of cardiac vagal activity is associated with myocardial injury in patients undergoing noncardiac surgery: prospective observational mechanistic cohort study. Br J Anaesth. 2019;123(6):758-67.

17. Weise $F$, Heydenreich $F$, and Runge $U$. Contributions of sympathetic and vagal mechanisms to the genesis of heart rate fluctuations during orthostatic load: a spectral analysis. J Auton Nerv Syst. 1987;21(2-3):127-34.

18. Goldstein DS, Bentho O, Park MY, and Sharabi Y. Low-frequency power of heart rate variability is not a measure of cardiac sympathetic tone but may be a measure of modulation of cardiac autonomic outflows by baroreflexes. Exp Physiol. 2011;96(12):1255-61. 
medRxiv preprint doi: https://doi.org/10.1101/2021.01.28.21249488; this version posted January 28, 2021. The copyright holder for this preprint (which was not certified by peer review) is the author/funder, who has granted medRxiv a license to display the preprint in It is made available under a CC-BY-NC-ND 4.0 International license .

19. Millar PJ, Cotie LM, St Amand T, McCartney N, and Ditor DS. Effects of autonomic blockade on nonlinear heart rate dynamics. Clinical autonomic research : official journal of the Clinical Autonomic Research Society. 2010;20(4):241-7.

20. Tarzami ST, Miao W, Mani K, Lopez L, Factor SM, Berman JW, et al. Opposing effects mediated by the chemokine receptor CXCR2 on myocardial ischemia-reperfusion injury: recruitment of potentially damaging neutrophils and direct myocardial protection. Circulation. 2003;108(19):2387-92.

21. Cheng YF, Chang YT, Chen WH, Shih HC, Chen YH, Shyu BC, et al. Cardioprotection induced in a mouse model of neuropathic pain via anterior nucleus of paraventricular thalamus. Nat Commun. 2017;8(1):826.

22. Tang $\mathrm{Y}$, Shah H, Bueno Junior CR, Sun X, Mitri J, Sambataro M, et al. Intensive Risk Factor Management and Cardiovascular Autonomic Neuropathy in Type 2 Diabetes: The ACCORD Trial. Diabetes Care. 2020.

23. Jensen RV, Stottrup NB, Kristiansen SB, and Botker HE. Release of a humoral circulating cardioprotective factor by remote ischemic preconditioning is dependent on preserved neural pathways in diabetic patients. Basic Res Cardiol. 2012;107(5):285.

24. Wang X, Huang ZG, Gold A, Bouairi E, Evans C, Andresen MC, et al. Propofol modulates gamma-aminobutyric acid-mediated inhibitory neurotransmission to cardiac vagal neurons in the nucleus ambiguus. Anesthesiology. 2004;100(5):1198-205.

25. Monfredi O, Lyashkov AE, Johnsen AB, Inada S, Schneider H, Wang R, et al. Biophysical characterization of the underappreciated and important relationship between heart rate variability and heart rate. Hypertension. 2014;64(6):1334-43.

26. Dantas EM, Sant'Anna ML, Andreao RV, Goncalves CP, Morra EA, Baldo MP, et al. Spectral analysis of heart rate variability with the autoregressive method: what model order to choose? Comput Biol Med. 2012;42(2):164-70.

27. Palatianos GM, Balentine G, Papadakis EG, Triantafillou CD, Vassili MI, Lidoriki A, et al. Neutrophil depletion reduces myocardial reperfusion morbidity. Ann Thorac Surg. 2004;77(3):956-61.

28. Litt MR, Jeremy RW, Weisman HF, Winkelstein JA, and Becker LC. Neutrophil depletion limited to reperfusion reduces myocardial infarct size after 90 minutes of ischemia. Evidence for neutrophil-mediated reperfusion injury. Circulation. 1989;80(6):1816-27.

29. Margraf A, Ley K, and Zarbock A. Neutrophil Recruitment: From Model Systems to TissueSpecific Patterns. Trends Immunol. 2019;40(7):613-34.

30. Torres-Gomez A, Cabanas C, and Lafuente EM. Phagocytic Integrins: Activation and Signaling. Front Immunol. 2020;11:738.

31. Lefer DJ, Shandelya SM, Serrano CV, Jr., Becker LC, Kuppusamy P, and Zweier JL. Cardioprotective actions of a monoclonal antibody against CD-18 in myocardial ischemiareperfusion injury. Circulation. 1993;88(4 Pt 1):1779-87.

32. Andersson U, and Tracey KJ. Reflex principles of immunological homeostasis. Annu Rev Immunol. 2012;30:313-35.

33. Kanashiro A, Hiroki CH, da Fonseca DM, Birbrair A, Ferreira RG, Bassi GS, et al. The role of neutrophils in neuro-immune modulation. Pharmacol Res. 2020;151:104580.

34. Benhammou K, Lee M, Strook M, Sullivan B, Logel J, Raschen K, et al. [(3)H]Nicotine binding in peripheral blood cells of smokers is correlated with the number of cigarettes smoked per day. Neuropharmacology. 2000;39(13):2818-29.

35. Haeusler KG, Schmidt WU, Foehring F, Meisel C, Guenther C, Brunecker P, et al. Immune responses after acute ischemic stroke or myocardial infarction. Int J Cardiol. 2010.

36. Fraccarollo D, Neuser J, Möller J, Galuppo P, and Bauersachs J. Expansion of CD14+HLADRneg/low monocytes and CD10neg neutrophils driving proinflammatory responses in patients with acute myocardial infarction. bioRxiv

2020;2020.09.21.306118(2020.09.21.306118). 
medRxiv preprint doi: https://doi.org/10.1101/2021.01.28.21249488; this version posted January $28,2021$. The copyright holder for this preprint (which was not certified by peer review) is the author/funder, who has granted medRxiv a license to display the preprint in It is made available under a CC-BY-NC-ND 4.0 International license.

37. Heusch G, and Rassaf T. Time to Give Up on Cardioprotection? A Critical Appraisal of Clinical Studies on Ischemic Pre-, Post-, and Remote Conditioning. Circ Res. 2016;119(5):676-95.

38. Basalay MV, Davidson SM, Gourine AV, and Yellon DM. Neural mechanisms in remote ischaemic conditioning in the heart and brain: mechanistic and translational aspects. Basic Res Cardiol. 2018;113(4):25.

39. Kazamel M, Stino AM, and Smith AG. Metabolic syndrome and peripheral neuropathy. Muscle Nerve. 2020.

40. Ackland GL, Minto G, Clark M, Whittle J, Stephens RCM, Owen T, et al. Autonomic regulation of systemic inflammation in humans: A multi-center, blinded observational cohort study. Brain Behav Immun. 2018;67:47-53.

41. Ackland GL, Abbott TEF, Minto G, Clark M, Owen T, Prabhu P, et al. Heart rate recovery and morbidity after noncardiac surgery: Planned secondary analysis of two prospective, multicentre, blinded observational studies. PLoS One. 2019;14(8):e0221277.

42. Machhada A, Trapp S, Marina N, Stephens RCM, Whittle J, Lythgoe MF, et al. Vagal determinants of exercise capacity. Nat Commun. 2017;8:15097.

43. Jin Z, Choi MJ, Park CS, Park YS, and Jin YH. Propofol facilitated excitatory postsynaptic currents frequency on nucleus tractus solitarii (NTS) neurons. Brain Res. 2012;1432:1-6.

44. Wang X. Propofol and isoflurane enhancement of tonic gamma-aminobutyric acid type a current in cardiac vagal neurons in the nucleus ambiguus. Anesth Analg. 2009;108(1):142-8.

45. Karmali SN, Sciusco A, May SM, and Ackland GL. Heart rate variability in critical care medicine: a systematic review. Intensive Care Med Exp. 2017;5(1):33. 